\title{
THE DECLINING RED LECHWE
}

\section{By W. F. H. ANsel.}

There are two forms of lechwe, the typical Red Lechwe (Onotragus leche leche. Gray) and the Black (O.l. smithemani. Lyd.), while a few surviving in the Mweru area to the north-west of the smithemani race, are of doubtful status. The present paper considers the red lechwe only, and that within Northern Rhodesia proper. The author has no knowledge of the animal outside the territory, nor in the Barotse province.

The lechwe, more than any other animal, is typical of Northern Rhodesia, for although there is some overlapping in the southwest into Angola and the Caprivi, by far the greater part of its range lies within that territory. Its preservation as a " national" animal is therefore of importance, but as the Director of Game and Tsetse Control in his report for 1953 says "... it is obvious that the numbers of both races of this most typically Northern Rhodesian antelope have declined alarmingly in recent years. None of the existing game reserves cover the main haunts of cither race. ...' In fact the only red lechwe in a permanent sanctuary anywhere are a small herd in the Busanga area of the Kafue National Park. In 19.18 this herd numbered less than a hundred but, under careful protection, has increased to 300 or cven more.

In former times the red lechwe was probably found wherever the habitat was suitable and some still exist in the Balovale district and possibly on the Manyinga river, but the only area where they remain in quantity is the vast flood plain of the Kafue flats. These flats lie for 140 miles along both sides of the Kafue river, eastward from its junction with the Musa.

Past and Present Numbers.-On the Kafue flats the red lechwe once occurred in hundreds of thousands ; even as late as 1932 Captain C. R. S. Pitman reported " the estimate that there are to be found there an aggregate of at least a quarter of a million is, I believe, no exaggeration". There are certainly nothing like a quarter of a million lechwe to-day. Local residents have reported a very great decline in recent years and this is confirmed by survey flights and ground observations made during the last two years by myself and by other members of the Game and Tsetse Department. We estimate that there are now only twenty-five or twenty-six thousand in the main body ; with this estimate Mr. L. E. Vaughan, senior ranger of the Iafue park, agrees. 
Distribution on the Kafuc Flats.-There is a small outlying group-possibly no more than 150-about twenty miles west of Namwala boma. After this there are none, save possibly a few stragglers, until some six miles west of $27^{\circ} \mathrm{E}$. meridian, when the westward limit of the main herds is reached, see map. These big herds stretch from the Bwengwa and Lochinvar ranch, south of the river, through native reserve territory to the Blue Lagoon ranch in the north. In the dry season only, they extend along the southern bank of the Luwato lagoon as far as its southward bend. These places are the last stronghold of the red lechwe.

On the Veterinary Department research station there are some herds-probably not over a thousand animals all told-and there are small groups on private farms castwards along the Kafue to about the end of the flats.

It was especially noticeable in our surveys that a vast area of apparently suitable country contained no lechwe, even allowing for seasonal migration caused by the advance and fall of the floods. Some places scemingly suitable, but without resident lechwe are : the immediate vicinity of Namwala boma; Ibamba Ranch and the Kasenga Mission, with the country some way east of them; both banks of the Kafuc from the north-cast corner of Lochinvar to the Research Station; the lower Luwato lagoon and east to the Mwembeshi.

There can be little doubt that in all these places the lechwe have been wiped out by human agency, though it is not easy to apportion the blame. The European blames the African for destruction of game; the African lays it at the European's door. I do not here say more than that whereas cast of the Luwato lagoon, and perhaps in one or two other places, the European of the less responsible sort has, in the past, wrought great havoc among the lechwe, the places to the west have for a very long time indecd been native reserve and the influence of the "biltong hunter" not so great.

The Legal Position.-The red lechwe is totally protected on the north side of the Kafuc, though it is extremely difficult, and often impossible, to cnsure that the law is observed. On the south side the shooting limit is ten per game licence, a survival from former times and much too high to-dny.

'The new Fauma Conservation Bill allows four (only in the southern province and only on the south side of the Kafue). No one not resident in the native reserve may hunt game thercin exeept with special permission, which is not normally granted. No one may hunt on private land without the permission of the 
owner or occupier. There is therefore little opportunity now for the European to kill lechwe on any great scalc.

The Chila.-The only killing of lechwe that is of major importance to-day is the native lechwe drive, or "Chila ", a traditional African way of hunting. The animals are driven, and if possible surrounded, by lines of beaters, while with the help of dogs the hunters try to spear them. Like so many other primitive forms of hunting, the Chila in its original form probably did little more than take the surplus crop of game, but in recent years the picture has changed. The means to purchase shotguns, improved transport to distribute the meat and ready markets in the big

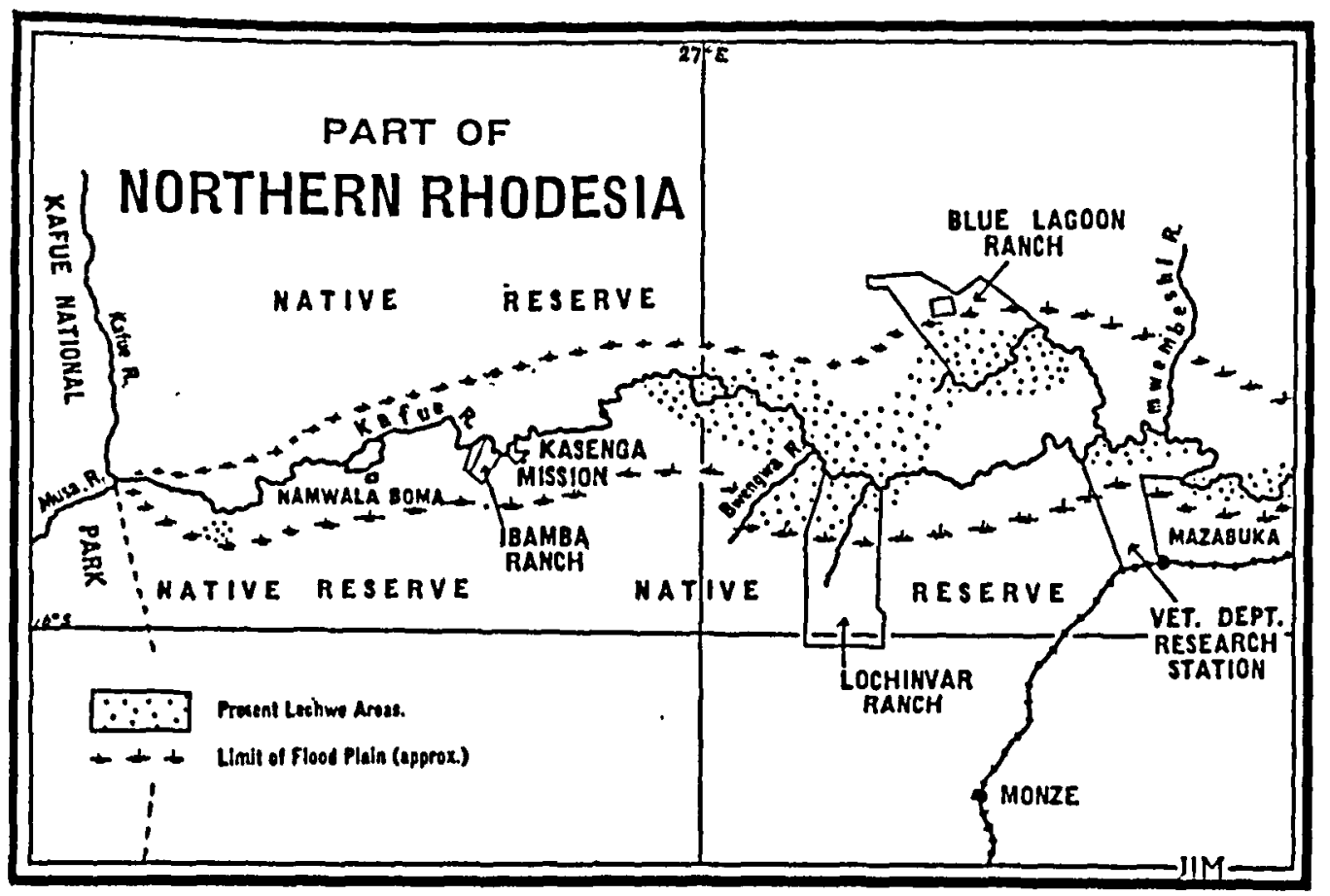

towns have all had their effect. Although it is illegal, there is no doubt that a good denl of selling of lechwe meat goes on, but it is extremely difficult to detect and prove. Instead of mercly filling the pot, as in former times, the hunting of lechwe is tending to become a commercial proposition. Those familiar with wild life management will know what this means.

The African has a strong sense of the traditional and his claim to proprictary rights over the lechwe cannot be ignored. There is a sporting atmosphere about $\Omega$ Chiln and, in the words of one observer, it seems to be conducted in the same spirit as a fox hunt or a race mecting. While one cannot but look with disfnvour at the number of immature animals that fall victim, there is nothing in the Chila, as a method of taking game, that 
could be objected to by any upholder of field sports, and it certainly involves both skill and strenuous physical effort. I consider it important to remember this aspect of the matter, for the African is far more likely to support conservation measures aimed at preserving his sport-as well of course as his meat supply - than he would be to co-operate in preservation for its own sake, an academic consideration quitc outside his apparent interest or present understanding.

On the other hand there is no doubt that the chilas are wickedly destructive and take very high annual toll of the remaining herds. 'There is in fact a possibility of the complete extermination of the lechwe in those areas where drives are practised. No solution to this problem has yet been found, but at present it is likely to lic in the direction of control rather than in any attempt at abolition.

The Future of the Red Lechwe.-I do not know the outlook for the red lechwe in Angola or the Caprivi ; in Barotse province and Balovale district there secms no great prospect of its survival.

The Busanga herd in the Kafue park might save it from extermination but one hopes that survival will not depend on one small group, however well protected. On the land occupied by Europeans the lechwe are protected, at least from organized drives, but have no permanent security.

The best solution to the lechwe question would be the creation of an adequate reserve, but to quote again the 1953 officinl report, "The main red lechwe haunts, the Kafue flats, is so hedged about with private land and native reserve that the provision of an adequate sanctuary presents the utmost difficulty ". There is also the proposed Kafue hydro-electric scheme. Although the extent of the flooding likely to be caused by the barrage has not yet been made known, one supposes that the habitat and seasonal movement of the lechwe will be considerably affected.

These are the problems which the Department of Game and Isetse Control has to face in preserving the red lechwe in Northern Rhodesia. Wild animal lovers everywhere will hope that a satisfactory solution will be found.

Note.-Mr. W. F. H. Ansell is a member of the Northern Rhodesia Game and Tsetse Department. We are particularly pleased to publish his article at the present moment, because there is hope that the Lochinvar ranch may become the permanent lechwe sanctuary for which Mr. Ansell calls.-Ed. 


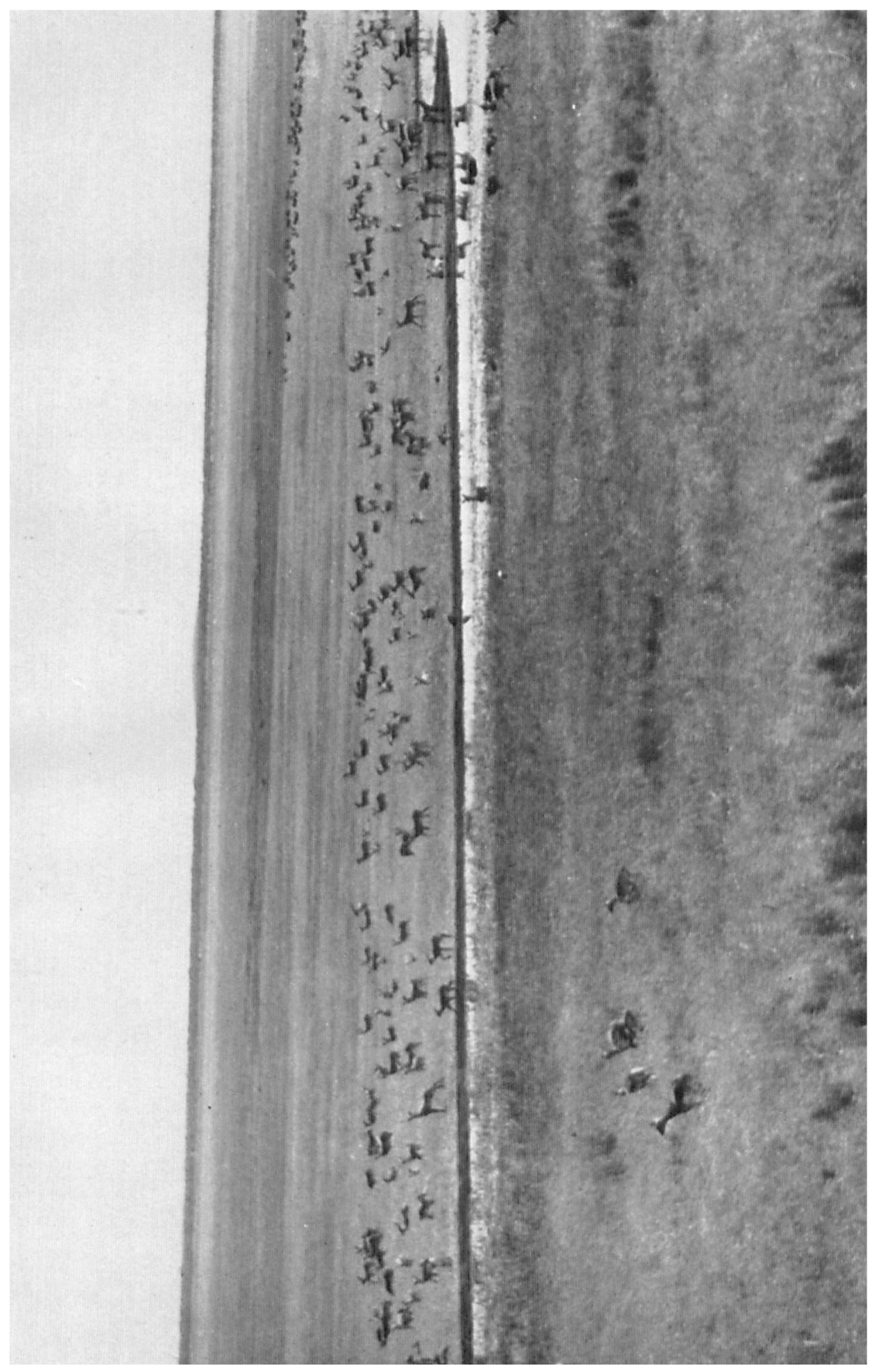

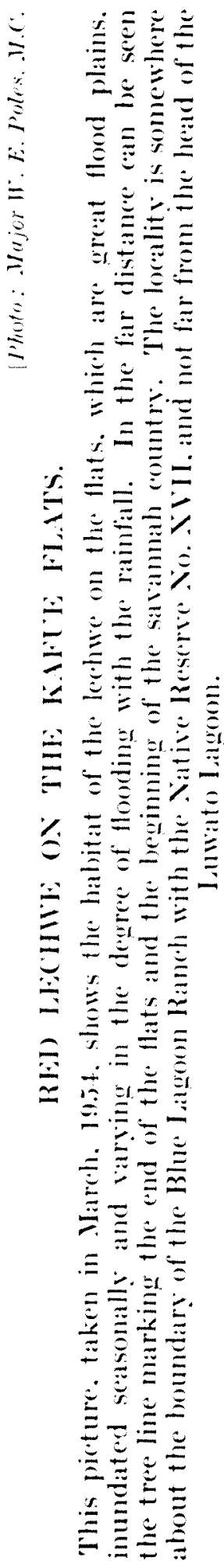




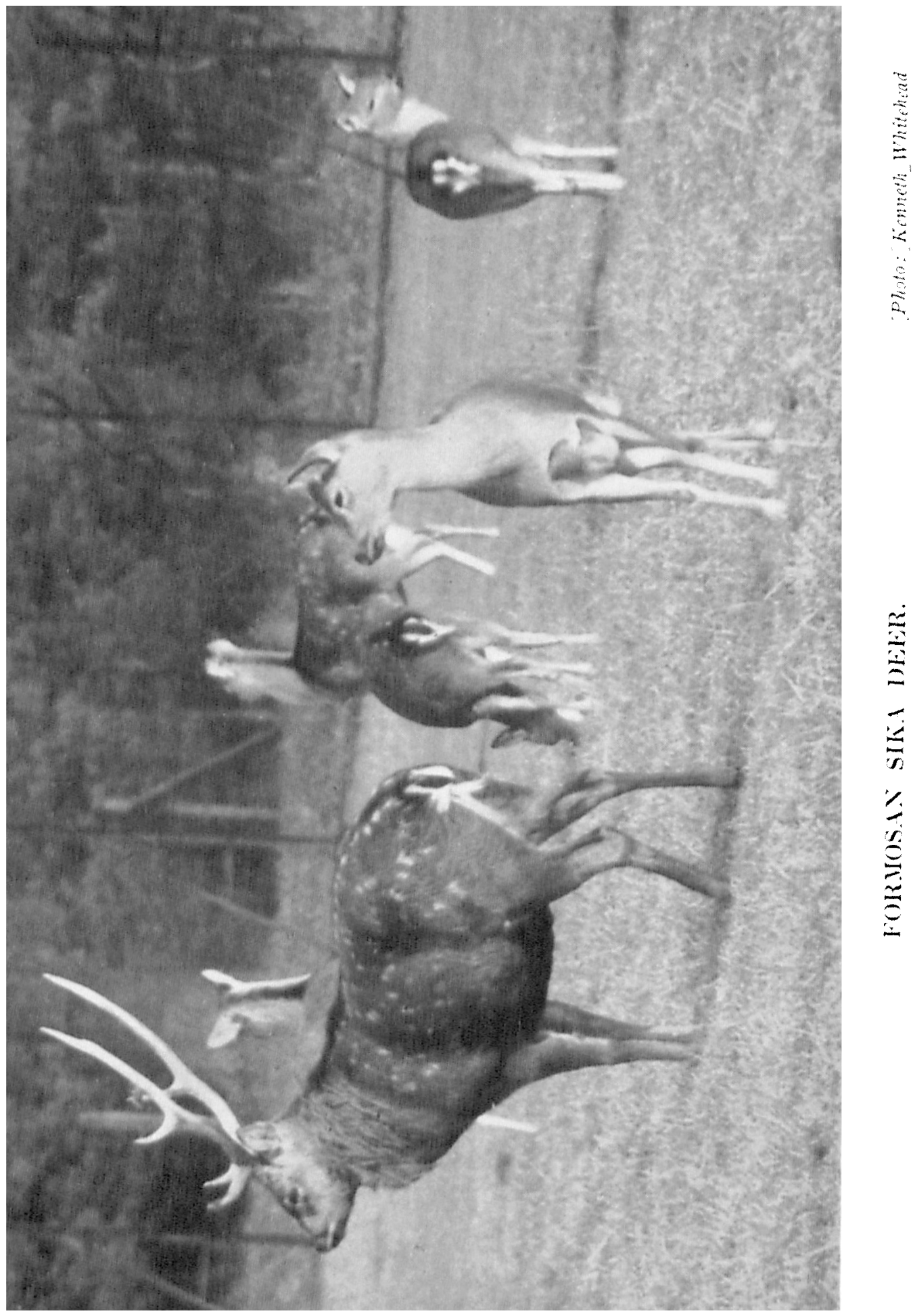

